\title{
The Comparison of High School Students' Level of Aggression Based on Demographic Features
}

\author{
Oktay ÇOBAN ${ }^{1} \bowtie$ \\ Mehmet YILDIRIM ${ }^{2}$ \\ University of Yozgat Bozok, School of Physical Education and Sports, Yozgat, Turkey \\ Email: oktay.coban@bozok.edu.tr
}

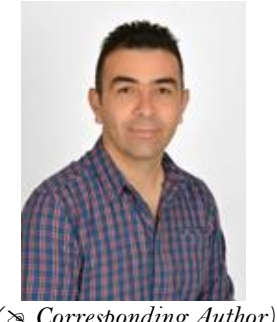

\begin{abstract}
This study aims to determine high school students' level of aggression and compare their level of aggression based on some demographic features. The population of the study comprises of high school students attending public and private schools in Yozgat province of Turkey during 20172018 school year. The sample of the study comprises of 300 students selected using random sampling method in public and private schools in Yozgat province of Turkey during 2017-2018 school year. The study benefits from survey as a method. Students' demographic features were obtained using "personal information form". "Buss Perry Aggresion Scale" was used to measure students' level of aggression. The obtained data were processed using SPSS 18 software program. Finally, frequency analysis, percentage analysis, arithmetic means, t test, ANOVA and post-hoc tests were used for data analysis. The findings of the study indicated statistically significant differences were found among students' level of aggression in terms of different variables such as their gender, age, school type, mother's employment status, mother's education level, monthly expenses and number of siblings $(\mathrm{p}<0.05)$.
\end{abstract}

Keywords: Aggression, High school, Student.

Citation | Oktay ÇOBAN; Mehmet YILDIRIM (2018). The Comparison of High School Students' Level of Aggression Based on Demographic Features. Asian Journal of Education and Training, 4(4): 363-370.

History:

Received: 31 May 2018

Revised: 16 July 2018

Accepted: 4 September 2018

Published: 9 October 2018

Licensed: This work is licensed under a Creative Commons

Attribution 3.0 License (cc) E E

Publisher:Asian Online Journal Publishing Group
Contribution/Acknowledgement: Both authors contributed to the conception and design of the study.

Funding: This study received no specific financial support.

Competing Interests: The authors declare that they have no conflict of interests.

Transparency: The authors confirm that the manuscript is an honest, accurate, and transparent account of the study was reported; that no vital features of the study have been omitted; and that any discrepancies from the study as planned have been explained.

Ethical: This study follows all ethical practices during writing.

\section{Contents}

1. Introduction

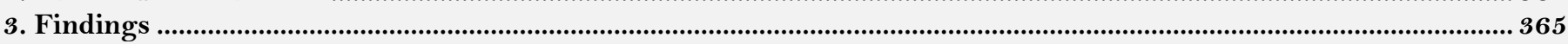

4. Discussion

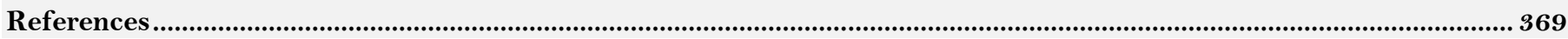




\section{Introduction}

Aggression involves deliberate attitudes and behaviors that aim to physically or emotionally damage another living being (Ballard et al., 2004) and is defined as deliberately injuring or damaging another person (Hetherington and Parke, 1993). From a theoretical perspective, whether aggression results from an individual's character or environmental factors and whether it can be controlled is a controversial issue. Emotional definitions of aggression associate it with a feeling of anger, while motivational definitions argue that only a person's intents determine whether a behavior is aggressive or not. Behaviors that directly aim to harm can be considered as aggressive. According to behavioral definitions, the intent underlying a behavior is not important and thus any behavior that physically or emotionally damages another person is aggression (Erkuş, 1994).

Aggression is theoretically divided into four categories as physical aggression, anger, hostility and indirect aggression (Buss and Warren, 2000). Another theory classifies aggression or violent behaviors as physical violence, verbal aggression, anger and inconsiderate or sudden aggressive behaviors (Novaco, 1994). Buss and Perry (1992) argues that physical, verbal and indirect aggression involved behaviors that aim to "hurt or harm" others, which represent the behavioral component of aggression. Freedman, Sears and Carlsmith categorizes aggression into three groups as altruistic (pro-social), hostile (anti-social) and allowed aggression. They also list causes of aggression as instinct, disturbance, frustration, emotive stimulation and elements controlling aggressive behaviors as learning, reinforcement and imitation (Freedman et al., 1998).

Schools have a very complex structure due to both its educational agents that comprise its body and students on whose behaviors these agents study. Any system that aims at educating people is called school and given different names such as university, faculty, institute, high school, primary school, nursery school etc (Başaran, 1996). It is one of the primary goals of schools to offer students an environment that prevents them from being immersed in useless behaviors and harmful habits or models (Başaran, 1996). Therefore, in order to fulfill this function, schools should aim at building a safe atmosphere which will exclude dangerous behaviors in the vicinity and thus set good examples and role models for students, providing students with a positive set of behaviors. However, students still witness examples of violence in schools such as beating, theft and aggression (Oğülmüş, 1995).

Family is one of the most important elements that influence an individual's level of aggression. For instance, Patterson (1974) states that children who grow up in a family with aggressive relationships tend to display more aggressive behaviors in the future. Similarly, Bandura (1983) believes that an individual encounters aggressive models in daily life in their family, sub-culture and mass communication tools. Children whose parents resort to physical punishment are more likely to display aggressive behaviors in their relationships with other people. It was demonstrated that parents who were exposed to domestic violence and abuse during their childhood treated their children in a very similar way. Yavuzer (1991) reports that children who are exposed to oppression and authoritarian, inconsistent attitudes by their parents display more aggressive behaviors later in their lives.

This study aims to determine high school students' level of aggression and compare their level of aggression based on some demographic features.

\section{Material and Methods}

This section describes the population, sample, data collection tools and data analysis of the present study.

\subsection{The Population and Sample of the Study}

The population of the study comprises of high school students attending public and private schools in Yozgat province of Turkey during 2017-2018 school year. The sample of the study comprises of 300 students selected using random sampling method in public and private schools in Yozgat province of Turkey during 2017-2018 school year.

\subsection{Data Collection Tools}

In the present study, students' demographic features were obtained using "personal information form”. "Buss Parry Aggresion Scale" was used to determine students' views on aggressive behaviors. Further information about data collection tool can be found in the following section.

\subsubsection{Buss Perry Aggression Scale}

This study benefits from Buss Perry aggression scale (Buss and Perry, 1992) which is a five-point Likert type scale (1- Absolutely Inappropriate, 2- Slightly Inappropriate, 3- Slightly Appropriate, 4- Appropriate 5- Absolutely Appropriate) consisting of four sub-dimensions (physical aggression, anger, hostility and verbal aggression) and 29 items. Madran (2012) adapted the scale to Turkish context, and tested its reliability and validity. It focuses on four different sub-dimensions of aggression, namely as physical aggression, verbal aggression, anger and hostility. In this questionnaire, 9 questions $(13,8,2,11,25,16,29,22,5)$ address the sub-dimension of physical aggression related to giving physical damage to others, 5 questions $(27,6,21,14,4)$ address the sub-dimension of verbal aggression related to the tendency to hurt others verbally, 7 questions $(19,28,1,18,9,23,12)$ address the subdimension of anger to measure emotional aspect of aggression, and, finally, 8 questions $(20,24,3,7,26,10,15,17)$ address the sub-dimension of hostility to measure cognitive aspect of aggression. $9^{\text {th }}$ and $16^{\text {th }}$ items in the aggression scale are reverse coded. In Turkish version of Buss Perry aggression scale, Cronbach Alpha reliability coefficient was calculated as 0.85 for the whole scale, while physical aggression, verbal aggression, anger and hostility sub-dimension coefficients were obtained as 0.78, 0.48, 0.76 and 0.71 for, respectively (Madran, 2012).

The present study calculated Cronbach Alpha value as 0.88 for the whole scale. Additionally, it was calculated as $0.81,0.52,0.73$ and 0.70 for physical aggression, verbal aggression, anger and hostility sub-dimensions, respectively. A reliability coefficient varying between .70 and .90 means a high level of reliability (Bagozzi and Yi, 1988; Nunnally and Bernstein, 1994). Therefore, it can be safely argued that that the scale is acceptable in terms of internal reliability coefficients. 


\subsubsection{Data Analysis}

The data obtained from the present study were transferred to SPSS 18 statistics program. In the data analysis, frequency, percentage and arithmetic means analyses were used to describe students' demographic features. In addition, Cronbach alpha was used to test scale reliability, $t$ test and ANOVA were used to determine differences between mean total aggression scores and mean sub-dimension scores in terms of demographic variables, and, finally, post hoc (Tukey, Tamhane 2 ) tests were used depending on the variance homogeneity.

\section{Findings}

Findings related to students' demographic features are given in Table 1.

Table-1. Findings related to students' demographic features

\begin{tabular}{|c|c|c|c|}
\hline & & $\mathbf{N}$ & $\%$ \\
\hline \multirow[t]{2}{*}{ Gender } & Male & 150 & 50.0 \\
\hline & Female & 150 & 50.0 \\
\hline \multirow{6}{*}{ Age } & 14 & 13 & 4.3 \\
\hline & 15 & 70 & 23.3 \\
\hline & 16 & 85 & 28.3 \\
\hline & 17 & 84 & 28.0 \\
\hline & 18 & 40 & 13.3 \\
\hline & 19 & 8 & 2.7 \\
\hline \multirow{4}{*}{ Residence Type } & With Family & 209 & 69.7 \\
\hline & With Relatives & 2 & .7 \\
\hline & At Dormitory & 85 & 28.3 \\
\hline & With (a) flat mate(s) & 4 & 1.3 \\
\hline \multirow[t]{2}{*}{ School Type } & Public school & 150 & 50.0 \\
\hline & Private School & 150 & 50.0 \\
\hline \multirow[t]{2}{*}{ Mother's Employment Status } & Employed & 71 & 23.7 \\
\hline & Non-employed & 229 & 76.3 \\
\hline \multirow{6}{*}{ Mother's Education Level } & Illiterate & 9 & 3.0 \\
\hline & Primary School & 100 & 33.3 \\
\hline & Secondary School & 71 & 23.7 \\
\hline & High School & 75 & 25.0 \\
\hline & University & 37 & 12.3 \\
\hline & Post-graduate & 8 & 2.7 \\
\hline \multirow{5}{*}{ Father's Education Level } & Primary School & 47 & 15.7 \\
\hline & Secondary School & 61 & 20.3 \\
\hline & High School & 108 & 36.0 \\
\hline & University & 74 & 24.7 \\
\hline & Post-graduate & 10 & 3.3 \\
\hline \multirow{5}{*}{ Monthly Expenses } & $250 \mathrm{TL}$ and less & 64 & 21.3 \\
\hline & $251 \mathrm{TL}-500 \mathrm{TL}$ & 76 & 25.3 \\
\hline & $501 \mathrm{TL}-750 \mathrm{TL}$ & 68 & 22.7 \\
\hline & $751 \mathrm{TL}-1000 \mathrm{TL}$ & 43 & 14.3 \\
\hline & $1001 \mathrm{TL}$ and more & 49 & 16.3 \\
\hline \multirow{6}{*}{ Number of Siblings } & No siblings & 18 & 6.0 \\
\hline & 1 sibling & 105 & 35.0 \\
\hline & 2 siblings & 85 & 28.3 \\
\hline & 3 siblings & 50 & 16.7 \\
\hline & 4 siblings & 26 & 8.7 \\
\hline & 5 siblings and more & 16 & 5.3 \\
\hline
\end{tabular}

Table-2. Aggression scale mean total scores

\begin{tabular}{l|l|l|l|l|l}
\hline Aggression Scale & N & Minimum & Maximum & Mean & Standard Deviation \\
\hline & 300 & 34.00 & 124.00 & 80.54 & 18.51 \\
\hline
\end{tabular}

When Table 2 is analyzed, it can be noted that the minimum and maximum aggression scale scores were 34 and 124, respectively, and mean score was 80.54 . Therefore, it can be argued that students in the study group do not display highly aggressive behaviors.

Table-3. Aggression scale mean sub-dimension scores

\begin{tabular}{l|l|l|l}
\hline Buss Perry Aggression Scale Sub-dimensions & N & Mean & Standard Deviation \\
\hline Physical Aggression & 300 & 2.58 & .82 \\
\hline Verbal Aggression & 300 & 2.78 & .71 \\
\hline Anger & 300 & 2.84 & .83 \\
\hline Hostility & 300 & 2.93 & .78 \\
\hline
\end{tabular}

It can be observed in Table 3 that the highest aggression level among sub-dimension is hostility $(\overline{\mathrm{x}}=2.93)$. 
Table-4. $\mathrm{t}$ test findings related to mean sub-dimension scores in terms of gender

\begin{tabular}{|c|c|c|c|c|c|c|}
\hline & Gender & $\mathbf{N}$ & Mean Score & Sd & $\mathbf{t}$ & p \\
\hline \multirow[t]{2}{*}{ Physical Aggression } & Male & 150 & 2.74 & .767 & \multirow[t]{2}{*}{3.41} & \multirow[t]{2}{*}{.001} \\
\hline & Female & 150 & 2.42 & .853 & & \\
\hline \multirow[t]{2}{*}{ Verbal Aggression } & Male & 150 & 2.77 & .700 & \multirow[t]{2}{*}{-.193} & \multirow[t]{2}{*}{.847} \\
\hline & Female & 150 & 2.79 & .734 & & \\
\hline \multirow[t]{2}{*}{ Anger } & Male & 150 & 2.79 & .743 & \multirow[t]{2}{*}{-1.071} & \multirow[t]{2}{*}{.285} \\
\hline & Female & 150 & 2.89 & .911 & & \\
\hline \multirow[t]{2}{*}{ Hostility } & Male & 150 & 2.80 & .702 & \multirow[t]{2}{*}{-2.831} & \multirow[t]{2}{*}{.005} \\
\hline & Female & 150 & 3.05 & .840 & & \\
\hline
\end{tabular}

Table 4 indicates that a statistically significant difference was found among mean sub-dimension scores for physical aggression and hostility in terms of gender $(\mathrm{p}<.05)$. While male students had a higher level of aggression compared to female students in the sub-dimension of physical aggression, female students had a higher level of aggression compared to male students in the sub-dimension of hostility.

Table-5. ANOVA findings related to mean sub-dimension scores in terms of age

\begin{tabular}{|c|c|c|c|c|}
\hline & & sd & $\mathbf{F}$ & $\mathbf{p}$ \\
\hline \multirow[t]{3}{*}{ Physical Aggression } & Between groups & 5 & \multirow[t]{3}{*}{1.63} & \multirow[t]{3}{*}{.150} \\
\hline & Within groups & 294 & & \\
\hline & Total & 299 & & \\
\hline \multirow[t]{3}{*}{ Verbal Aggression } & Between groups & 5 & \multirow[t]{3}{*}{3.03} & \multirow[t]{3}{*}{$.011^{*}$} \\
\hline & Within groups & 294 & & \\
\hline & Total & 299 & & \\
\hline \multirow[t]{3}{*}{ Anger } & Between groups & 5 & \multirow[t]{3}{*}{2.47} & \multirow[t]{3}{*}{$.033^{*}$} \\
\hline & Within groups & 294 & & \\
\hline & Total & 299 & & \\
\hline \multirow[t]{3}{*}{ Hostility } & Between groups & 5 & \multirow[t]{3}{*}{3.10} & \multirow[t]{3}{*}{$.009^{* *}$} \\
\hline & Within groups & 294 & & \\
\hline & Total & 299 & & \\
\hline
\end{tabular}

Table 5 indicates that statistically significant differences were found among mean sub-dimension scores for physical aggression, anger and hostility in terms of age $(\mathrm{p}<.05)$.

\begin{tabular}{l|c|c|c|c|c}
\multicolumn{2}{c}{ Table-6. Multiple comparison test results for the significant difference related to mean sub-dimension scores in terms of age } \\
\hline & Age & & Mean Difference & Standard Error & p \\
\hline Verbal Aggression & 14 years & 16 years & -.68 & .20 & .016 \\
& & 18 years & -.64 & .22 & .048 \\
\hline Anger & 14 years & 16 years & -.54 & .24 & .026 \\
& & 18 years & -.70 & .26 & .007 \\
\hline Hostility & \multirow{2}{*}{14 years } & 16 years & -.61 & .22 & .007 \\
& & 17 years & -.56 & .24 & .015 \\
& & 18 years & -.55 & .34 & .024 \\
& & 19 years & -.76 & & .029 \\
\hline
\end{tabular}

It can be understood from Table 6 that a statistically significant difference was found between students aged 14 years and those aged 16 and 18 years old for verbal aggression and anger $(\mathrm{p}<.05)$. This difference is in favor of those aged 16 and 18 years old. In the sub-dimension of hostility, similarly, a significant difference was found between students aged 14 years old and those aged 16,17,18 and 19 years old. This difference is in favor of those aged 16, 17, 18 and 19 years old. Therefore, it can be suggested that increasing age is directly proportional to aggressive behaviors.

Table-7. ANOVA findings related to mean sub-dimension scores in terms of residence type

\begin{tabular}{|c|c|c|c|c|}
\hline & & sd & $\mathbf{F}$ & p \\
\hline \multirow[t]{3}{*}{ Physical Aggression } & Between groups & 3 & \multirow[t]{3}{*}{1.772} & \multirow[t]{3}{*}{.152} \\
\hline & Within groups & 296 & & \\
\hline & Total & 299 & & \\
\hline \multirow[t]{3}{*}{ Verbal Aggression } & Between groups & 3 & \multirow[t]{3}{*}{.536} & \multirow[t]{3}{*}{.658} \\
\hline & Within groups & 296 & & \\
\hline & Total & 299 & & \\
\hline \multirow[t]{3}{*}{ Anger } & Between groups & 3 & \multirow[t]{3}{*}{2.360} & \multirow[t]{3}{*}{.072} \\
\hline & Within groups & 296 & & \\
\hline & Total & 299 & & \\
\hline \multirow[t]{3}{*}{ Hostility } & Between groups & 3 & \multirow[t]{3}{*}{1.297} & \multirow[t]{3}{*}{.276} \\
\hline & Within groups & 296 & & \\
\hline & Total & 299 & & \\
\hline
\end{tabular}

Table 7 indicates no statistically significant differences among mean sub-dimension scores in terms of residence type $(\mathrm{p}>.05)$. 
Table-8. $\mathrm{t}$ test findings related to mean sub-dimension scores in terms of school type

\begin{tabular}{|c|c|c|c|c|c|c|}
\hline & School Type & $\mathbf{N}$ & Mean & Sd & $\mathrm{t}$ & $\bar{p}$ \\
\hline \multirow[t]{2}{*}{ Physical Aggression } & Public school & 150 & 2.43 & .738 & \multirow[t]{2}{*}{-3.120} & \multirow[t]{2}{*}{.002} \\
\hline & Private school & 150 & 2.72 & .883 & & \\
\hline \multirow[t]{2}{*}{ Verbal Aggression } & Public school & 150 & 2.66 & .720 & \multirow[t]{2}{*}{-2.771} & \multirow[t]{2}{*}{.006} \\
\hline & Private school & 150 & 2.89 & .696 & & \\
\hline \multirow[t]{2}{*}{ Anger } & Public school & 150 & 2.73 & .798 & \multirow[t]{2}{*}{-2.296} & \multirow[t]{2}{*}{.022} \\
\hline & Private school & 150 & 2.95 & .852 & & \\
\hline \multirow[t]{2}{*}{ Hostility } & Public school & 150 & 2.83 & .722 & \multirow[t]{2}{*}{-2.055} & \multirow[t]{2}{*}{.041} \\
\hline & Private school & 150 & 3.02 & .833 & & \\
\hline
\end{tabular}

It can be understood from Table 8 that a statistically significant difference was found among mean subdimension scores for physical aggression, verbal aggression, anger and hostility in terms of school type $(\mathrm{p}<.05)$. While students attending a public school had a higher level of aggression in the sub-dimension of physical aggression compared to those attending a private school, students attending a private school had a higher level of aggression compared to those attending a public school in other sub-dimensions.

Table-9. $t$ test findings related to mean sub-dimension scores in terms of mother's employment status

\begin{tabular}{|c|c|c|c|c|c|c|}
\hline & Employment Status & $\mathbf{N}$ & Mean & Ss & $\mathrm{t}$ & p \\
\hline \multirow[t]{2}{*}{ Physical Aggression } & Employed & 71 & 2.58 & .835 & \multirow[t]{2}{*}{.064} & \multirow[t]{2}{*}{.949} \\
\hline & Non-employed & 229 & 2.58 & .825 & & \\
\hline \multirow[t]{2}{*}{ Verbal Aggression } & Employed & 71 & 2.90 & .657 & \multirow[t]{2}{*}{1.603} & \multirow[t]{2}{*}{.110} \\
\hline & Non-employed & 229 & 2.74 & .731 & & \\
\hline \multirow[t]{2}{*}{ Anger } & Employed & 71 & 2.82 & .818 & \multirow[t]{2}{*}{-298} & \multirow[t]{2}{*}{.766} \\
\hline & Non-employed & 229 & 2.85 & .837 & & \\
\hline \multirow[t]{2}{*}{ Hostility } & Employed & 71 & 3.09 & .798 & \multirow[t]{2}{*}{1.999} & \multirow[t]{2}{*}{.047} \\
\hline & Non-employed & 229 & 2.88 & .774 & & \\
\hline
\end{tabular}

Table 9 indicates that a statistically significant difference was found among mean sub-dimension scores for hostility in terms of mother's employment status $(p<.05)$. It was found out that students whose mothers were employed had a higher level of aggression in the sub-dimension of hostility.

Table-10. ANOVA findings related to mean sub-dimension scores in terms of mother's education level

\begin{tabular}{|c|c|c|c|c|}
\hline & & sd & $\mathbf{F}$ & $\bar{p}$ \\
\hline \multirow[t]{3}{*}{ Physical Aggression } & Between groups & 5 & \multirow[t]{3}{*}{.400} & \multirow[t]{3}{*}{.849} \\
\hline & Within groups & 294 & & \\
\hline & Total & 299 & & \\
\hline \multirow[t]{3}{*}{ Verbal Aggression } & Between groups & 5 & \multirow[t]{3}{*}{2.594} & \multirow[t]{3}{*}{$.026^{*}$} \\
\hline & Within groups & 294 & & \\
\hline & Total & 299 & & \\
\hline \multirow[t]{3}{*}{ Anger } & Between groups & 5 & \multirow[t]{3}{*}{4.069} & \multirow[t]{3}{*}{$.001^{* *}$} \\
\hline & Within groups & 294 & & \\
\hline & Total & 299 & & \\
\hline \multirow[t]{3}{*}{ Hostility } & Between groups & 5 & \multirow[t]{3}{*}{2.699} & \multirow[t]{3}{*}{$.021^{*}$} \\
\hline & Within groups & 294 & & \\
\hline & Total & 299 & & \\
\hline
\end{tabular}

${ }^{*} \mathrm{p}<.05,{ }^{* *} \mathrm{p}<.01$

Table 10 indicates that a statistically significant difference was found among mean sub-dimension scores for verbal aggression, anger and hostility in terms of mother's education level $(\mathrm{p}<.05)$.

Table-11. Multiple comparison test results for the significant difference related to mean sub-dimension scores in terms of mother's education level

\begin{tabular}{|c|c|c|c|c|c|}
\hline & Mother's Educat & Level & Mean Differences & Standard Error & p \\
\hline Verbal Aggression & $\begin{array}{l}\text { Secondary School } \\
\text { Primary School }\end{array}$ & $\begin{array}{l}\text { High school } \\
\text { University } \\
\text { High school }\end{array}$ & $\begin{array}{l}-.36 \\
-.29 \\
-.27 \\
\end{array}$ & $\begin{array}{l}.11 \\
.14 \\
.10 \\
\end{array}$ & $\begin{array}{l}.002 \\
.039 \\
.013 \\
\end{array}$ \\
\hline Anger & Illiterate & $\begin{array}{l}\text { Primary School } \\
\text { Secondary School } \\
\text { University } \\
\text { Post-graduate }\end{array}$ & $\begin{array}{l}.86 \\
.89 \\
.63 \\
1.14 \\
\end{array}$ & $\begin{array}{l}28 \\
.28 \\
.30 \\
.39 \\
\end{array}$ & $\begin{array}{l}.002 \\
.002 \\
.035 \\
.002 \\
\end{array}$ \\
\hline Hostility & $\begin{array}{l}\text { Secondary School } \\
\text { High school }\end{array}$ & $\begin{array}{l}\text { High school } \\
\text { University } \\
\text { Primary School }\end{array}$ & $\begin{array}{l}-.33 \\
-.34 \\
.27 \\
\end{array}$ & $\begin{array}{l}.12 \\
.15 \\
.11\end{array}$ & $\begin{array}{l}.010 \\
.028 \\
.021\end{array}$ \\
\hline
\end{tabular}

It can be seen in Table 11 that a statistically significant difference was found between students whose mothers graduated from secondary school and those whose mothers graduated from high school and university, and between students whose mothers graduated from primary school and high school in the sub-dimension of verbal aggression $(\mathrm{p}<.05)$. These differences are in favor of those who graduated from high school and university. In other words, students whose mothers graduated from high school and university display more verbal aggression. When it comes to the sub-dimension of anger, a statistically significant difference was found between students whose mothers were illiterate and those whose mothers graduated from primary, secondary and high school, university and post-graduate $(\mathrm{p}<.05)$. This difference is in favor of those whose mothers were illiterate. It is thus evident that 
students whose mothers were illiterate had a higher level of aggression in the sub-dimension of anger. In the subdimension of hostility, a statistically significant difference was found between students whose mothers graduated from secondary school and those whose mothers graduated from high school, and between students whose mother graduated from high school and those whose mothers graduated from primary and secondary school $(\mathrm{p}<.05)$. These differences are in favor of those whose mothers graduated from high school and university. To put it another way, students whose mothers graduated from high school and university had a higher level of aggression in the subdimension of hostility.

\begin{tabular}{|c|c|c|c|c|}
\hline & & sd & $\mathbf{F}$ & $\mathbf{p}$ \\
\hline \multirow[t]{3}{*}{ Physical Aggression } & Between groups & 4 & \multirow[t]{3}{*}{.450} & \multirow[t]{3}{*}{.773} \\
\hline & Within groups & 295 & & \\
\hline & Total & 299 & & \\
\hline \multirow[t]{3}{*}{ Verbal Aggression } & Between groups & 4 & \multirow[t]{3}{*}{1.129} & \multirow[t]{3}{*}{.343} \\
\hline & Within groups & 295 & & \\
\hline & Total & 299 & & \\
\hline \multirow[t]{3}{*}{ Anger } & Between groups & 4 & \multirow[t]{3}{*}{.686} & \multirow[t]{3}{*}{.602} \\
\hline & Within groups & 295 & & \\
\hline & Total & 299 & & \\
\hline \multirow[t]{3}{*}{ Hostility } & Between groups & 4 & \multirow[t]{3}{*}{1.256} & \multirow[t]{3}{*}{.287} \\
\hline & Within groups & 295 & & \\
\hline & Total & 299 & & \\
\hline
\end{tabular}

Table 12 indicates no statistically significant differences among mean sub-dimension scores in terms of father's education level $(\mathrm{p}>.05)$.

Table-13. ANOVA findings related to mean sub-dimension scores in terms of monthly expenses

\begin{tabular}{|c|c|c|c|c|}
\hline & & sd & $\mathbf{F}$ & p \\
\hline \multirow[t]{3}{*}{ Physical Aggression } & Between groups & 4 & \multirow[t]{3}{*}{2.387} & \multirow[t]{3}{*}{.051} \\
\hline & Within groups & 295 & & \\
\hline & Total & 299 & & \\
\hline \multirow[t]{3}{*}{ Verbal Aggression } & Between groups & 4 & \multirow[t]{3}{*}{2.221} & \multirow[t]{3}{*}{.067} \\
\hline & Within groups & 295 & & \\
\hline & Total & 299 & & \\
\hline \multirow[t]{3}{*}{ Anger } & Between groups & 4 & \multirow[t]{3}{*}{1.799} & \multirow[t]{3}{*}{.129} \\
\hline & Within groups & 295 & & \\
\hline & Total & 299 & & \\
\hline \multirow[t]{3}{*}{ Hostility } & Between groups & 4 & \multirow[t]{3}{*}{2.078} & \multirow[t]{3}{*}{.084} \\
\hline & Within groups & 295 & & \\
\hline & Total & 299 & & \\
\hline
\end{tabular}

Table 13 indicates no statistically significant differences among mean sub-dimension scores in terms of monthly expenses $(p>.05)$.

Table-14. ANOVA findings related to mean sub-dimension scores in terms of number of siblings

\begin{tabular}{|c|c|c|c|c|}
\hline & & sd & $\mathbf{F}$ & $\mathrm{p}$ \\
\hline \multirow[t]{3}{*}{ Physical Aggression } & Between groups & 5 & \multirow[t]{3}{*}{.326} & \multirow[t]{3}{*}{.897} \\
\hline & Within groups & 294 & & \\
\hline & Total & 299 & & \\
\hline \multirow[t]{3}{*}{ Verbal Aggression } & Between groups & 5 & \multirow[t]{3}{*}{2.658} & \multirow[t]{3}{*}{$.023^{3}$} \\
\hline & Within groups & 294 & & \\
\hline & Total & 299 & & \\
\hline \multirow[t]{3}{*}{ Anger } & Between groups & 5 & \multirow[t]{3}{*}{.314} & \multirow[t]{3}{*}{.904} \\
\hline & Within groups & 294 & & \\
\hline & Total & 299 & & \\
\hline \multirow[t]{3}{*}{ Hostility } & Between groups & 5 & \multirow[t]{3}{*}{1.090} & \multirow[t]{3}{*}{.366} \\
\hline & Within groups & 294 & & \\
\hline & Total & 299 & & \\
\hline
\end{tabular}

Multiple comparison test results for the significant difference related to mean sub-dimension scores in terms of number of siblings are given in Table 15.

Table-15. Multiple comparison test results for the significant difference related to mean sub-dimension scores in terms of number of siblings

\begin{tabular}{l|l|l|l|l|l}
\hline & Number of siblings & & Mean Differences & Standard Error & p \\
\hline Anger & 3 siblings & No siblings & -.59 & .19 & .002 \\
\hline & & 1 sibling & -.29 & .12 & .016 \\
\hline & & 2 siblings & -.29 & .12 & .019 \\
\hline
\end{tabular}

It can be understood from Table 15 that statistically significant differences were found between students who have 3 siblings and those who have no siblings, 1 sibling and 2 siblings in the sub-dimension of anger $(\mathrm{p}<.05)$. This 
difference is in favor of those who have no siblings, 1 sibling and siblings. Thus, it can be suggested that the number of siblings is directly proportional to the level of aggression.

\section{Discussion}

The findings of the present study indicate a statistically significant difference among high school students' mean sub-dimension scores in the sub-dimensions of physical aggression and hostility. While male students' level of aggression were higher compared to females when it comes to physical aggression, female students' level of aggression were higher compared to males in the sub-dimension of hostility.

Statistically significant differences were observed in the sub-dimensions of verbal aggression, anger and hostility in terms of age. A statistically significant difference was found between students aged 14 years and those aged 16 and 18 years old in the sub-dimensions of verbal aggression and anger. This difference is observed to be in favor of those aged 16 and 18 years old. In the sub-dimension of hostility, similarly, a significant difference was found between students aged 14 years old and those aged 16,17,18 and 19 years old. This difference is in favor of those aged 16, 17, 18 and 19 years old. Therefore, it is quite likely that age is directly proportional to increasing aggressive behaviors.

A statistically significant difference was found in the sub-dimensions of physical aggression, verbal aggression, anger and hostility in terms of school type. Whereas students attending a public school had a higher level of aggression in the sub-dimension of physical aggression compared to those attending a private school, students attending a private school had a higher level of aggression compared to those attending a public school in other sub-dimensions.

A statistically significant difference was observed in the sub-dimension of hostility in terms of mother's employment status. It was evident that students whose mothers were employed had a higher level of aggression in the sub-dimension of hostility.

A statistically significant difference was found in the sub-dimensions of verbal aggression, anger and hostility in terms of mother's education level. In the sub-dimension of verbal aggression, a statistically significant difference was found between students whose mothers graduated from secondary school and those whose mothers graduated from high school and university, and between students whose mothers graduated from primary school and high school. These differences are in favor of high school and university. In other words, students whose mothers graduated from high school and university display more verbal aggression. As for the sub-dimension of anger, a statistically significant difference was found between students whose mothers were illiterate and those whose mothers graduated from primary, secondary and high school, university and post-graduate. This difference is in favor of those whose mothers were illiterate. It can be stated that students whose mothers were illiterate had a higher level of aggression in the sub-dimension of anger. In the sub-dimension of hostility, a statistically significant difference was found between students whose mothers graduated from secondary school and those whose mothers graduated from high school, and between students whose mother graduated from high school and those whose mothers graduated from primary and secondary school. This difference is in favor of those whose mothers graduated from high school and university. In other words, students whose mothers graduated from high school and university had a higher level of aggression in the sub-dimension of hostility.

No statistically significant differences were observed among mean sub-dimensions scores in terms of father's education level, monthly expenses and residence type.

When students' level of aggression is analyzed in terms of number of siblings, statistically significant differences were found between students who have 3 siblings and those who have no siblings, 1 sibling and 2 siblings in the sub-dimension of anger. This difference is in favor of those who have no siblings, 1 sibling and siblings. It is evident that the number of siblings is directly proportional to the level of aggression.

- The present study was conducted in Yozgat province of Turkey. Further and extensive studies to be carried out in other regions and provinces will yield more holistic results.

- A different study focusing on a clear socio-economic level may be carried out in order to determine level of aggression among people with a high and low socio-economic status.

- The role of parents in child rearing is undeniable. In this respect, the relationship between parents' attitudes towards their children and aggression may be analyzed using different scales.

- New courses may be added to the school curricula in order to teach students how to solve and overcome their problems.

Students may be encouraged to explore their skills and thus participate in activities such as sports, art and music to keep them away from violence and aggression. In addition, new counselling systems may be designed to help talented students become specialized in these fields.

\section{References}

Bagozzi, R.P. and Y. Yi, 1988. On the evaluation of structural equation models. Journal of the Academy of Marketing Science, 16(1): 74-94.

Ballard, M.E., K.T. Rattley, W.C. Fleming and P. Kidder-Ashley, 2004. School aggression and dispositional aggression among middle school boys. RMLE Online, 27(1): 1-11. Available at: https://doi.org/10.1080/19404476.2004.11658163.

Bandura, A., 1983. Psychological mechanisms of aggression. (Ed.: R. G. Geen ve E. 1. Donnerstein). Aggression: Theoretical and empirical reviews. New York: Academic Press, 1: 1-35.

Başaran, I.E., 1996. Educational administration. Ankara: Yargıcı Publisher.

Buss, A. and M. Perry, 1992. The aggression questionnaire. Journal of Personality and Social Psychology, 63(3): 452-459.

Buss, A.H. and L.W. Warren, 2000. Aggression questionnaire: Manuel. Los Angeles CA: Western Psychological Services.

Erkuş, A., 1994. Glossary of psychology terms. Ankara: Doruk Publications.

Freedman, J.L., D.O. Sears and J.M. Carlsmith, 1998. Social psychology. Ankara: İmge Publisher.

Hetherington, E.M. and R.D. Parke, 1993. Child psychology. New York: McGraw-Hill.

Madran, H.A.D., 2012. Buss- reliability and validity of buss perry aggression scale in Turkish context. Turkish Journal of Psychology, 24(2): $1-6$.

Novaco, R.W., 1994. Anger as a risk factor for violence among the mentally disordered, (Ed), John Monahan\& Henry J. Steadman, Violence and mental disorder: Developments in risk assessment. Chicago: University of Chicago Press.

Nunnally, J.C. and I.H. Bernstein, 1994. Psychometric theory. New York: McGraw Hill. 
Oğülmüş, S., 1995. Violence and aggression in schools (High Schools). Unpublished Research Report.

Patterson, C.H., 1974. Relationship counseling and psychotherapy. New York: Harper \& Row Publishers.

Yavuzer, H., 1991. Parents and the child. Istanbul: Remzi Publisher. 